\title{
Modulation of Learning and Anxiety by Corticotropin-Releasing Factor (CRF) and Stress: Differential Roles of CRF Receptors 1 and 2
}

\author{
Jelena Radulovic, Andreas Rühmann, Thomas Liepold, and Joachim Spiess \\ Max Planck Institute for Experimental Medicine, Department for Molecular Neuroendocrinology, \\ 37075 Goettingen, Germany
}

\begin{abstract}
The differential modulation of learning and anxiety by corticotropin-releasing factor (CRF) through CRF receptor subtypes 1 (CRFR1) and 2 (CRFR2) is demonstrated. As learning paradigm, context- and tone-dependent fear conditioning of the mouse was used. Injection of CRF into the dorsal hippocampus before training enhanced learning through CRFR1 as demonstrated by the finding that this effect was prevented by the local injection of the unselective CRFR antagonist astressin, but not by the CRFR2-specific antagonist antisauvagine-30 (anti-Svg-30). In contrast, injection of CRF into the lateral intermediate septum impaired learning through CRFR2, as demonstrated by the ability of antisauvagine-30 to block this effect. When antisauvagine-30 was injected alone into the lateral intermediate septum, learning was enhanced. Such tonic control of learning was not observed when astressin or antisauvagine-30 was injected into the dorsal hippocampus.
\end{abstract}

Injection of CRF after the training into the dorsal hippocampus and the lateral intermediate septum also enhanced and impaired learning, respectively. Thus, it was indicated that CRF acted on memory consolidation. It was concluded that the observed effects reflected changes of associative learning and not arousal, attention, or motivation. Although a dose of 20 pmol human/rat CRF was sufficient to affect learning significantly, a fivefold higher dose was required to induce anxiety by injection into the septum. Immobilization for $1 \mathrm{hr}$ generated a stress response that included the induction of anxiety through septal CRFR2 and the subsequent enhancement of learning through hippocampal CRFR1. The involvement of either receptor subtype was demonstrated by region-specific injections of astressin and antisauvagine- 30 .

Key words: CRF receptor 1; CRF receptor 2; fear conditioning; anxiety; stress; hippocampus; lateral septum
Corticotropin-releasing factor (CRF), a 41 residue hypothalamic polypeptide (Spiess et al., 1981) that stimulates hypophyseal ACTH secretion (Vale et al., 1981), has been recognized as an early chemical signal that triggers endocrine responses to stress. In addition, CRF and the novel CRF-like peptide urocortin (Ucn) are widely distributed throughout the CNS of rodents and humans (Olschowka et al., 1982; Cummings et al., 1983; Vaughan et al., 1995; Kozicz et al., 1998), where they affect numerous behaviors such as locomotor activity, anxiety, food intake, and learning (Sutton et al., 1982; Dunn and Berridge, 1990; De Souza, 1995). CRF and Ucn exert their biological activity by binding to two types of CRF receptors (CRFRs), CRFR1 (Chen et al., 1993; Chang et al., 1993; Vita et al., 1993; Dautzenberg et al., 1998) and CRFR2 (Lovenberg et al., 1995; Perrin et al., 1995; Stenzel et al., 1995; Kishimoto et al., 1995), which show distinct distribution patterns in specific brain areas (Chalmers et al., 1995). In addition, both peptides bind to the CRF-binding protein (CRF-BP) (Potter et al., 1991, 1992). Thereby, the availability of free CRF or CRF-like peptides at their receptor sites (Behan et al., 1996) is reduced.

Modulation of learning and memory seems to be one of the

Received Dec. 23, 1998; revised March 17, 1999; accepted April 2, 1999.

This work was supported by the Max Planck Society, Germany. We thank André Fischer and Ulrike Katerkamp who worked as students in our laboratory, Oliver Stiedl and Ragna Lohmann for helpful discussions, and Almuth Burgdorf for assistance in the preparation of this manuscript.

Correspondence should be addressed to Jelena Radulovic, Max Planck Institute for Experimental Medicine, Department for Molecular Neuroendocrinology, Hermann-Rein-Strasse 3, 37075 Goettingen, Germany.

Copyright (C) 1999 Society for Neuroscience 0270-6474/99/195016-10\$05.00/0 major roles of CRF in rodent and human brain. Intracerebroventricular injections of CRF or its displacement from CRF-BP before or immediately after training enhances memory in multiple learning tasks (Koob and Bloom, 1985; Liang and Lee, 1988; Behan et al., 1995, Heinrichs et al., 1997), whereas intracerebroventricular administration before the memory test seems to impair memory (Diamant and De Wied, 1993). Increasing evidence suggests that these effects are independent of the arousal state, as indicated by the observation that CRF modulates learning and memory at a low dose that does not affect arousal, locomotion, or anxiety (Behan et al., 1995). Interestingly, higher doses of CRF typically induce anxiety, whereas displacement of CRF from its binding protein even by high doses of CRF-BP ligands enhances learning without affecting anxiety (Dunn and Berridge, 1990; Behan et al., 1995). So far, a role of CRFR2 and a relationship between CRFR1- and CRFR2-mediated behaviors of the brain CRF system have not been established.

In the present experiments, the role of CRFR1 and CRFR2 in learning and memory and in anxiogenesis were investigated using classic fear conditioning of mice to context and tone and the plus maze test. The experiments were targeted to the hippocampus and lateral intermediate septum. These two regions, which contain different amounts of CRFR1, CRFR2, and CRF-BP, are assumed to play an important role in associative learning. The hippocampus appears to be required for context-dependent (Kim and Fanselow, 1992; Phillips and LeDoux, 1992) and tonedependent fear conditioning (Maren et al., 1997), whereas the lateral septum mediates the impairment of conditioned fear responses (Thomas and Yadin, 1980; Yadin and Thomas, 1981; 
a

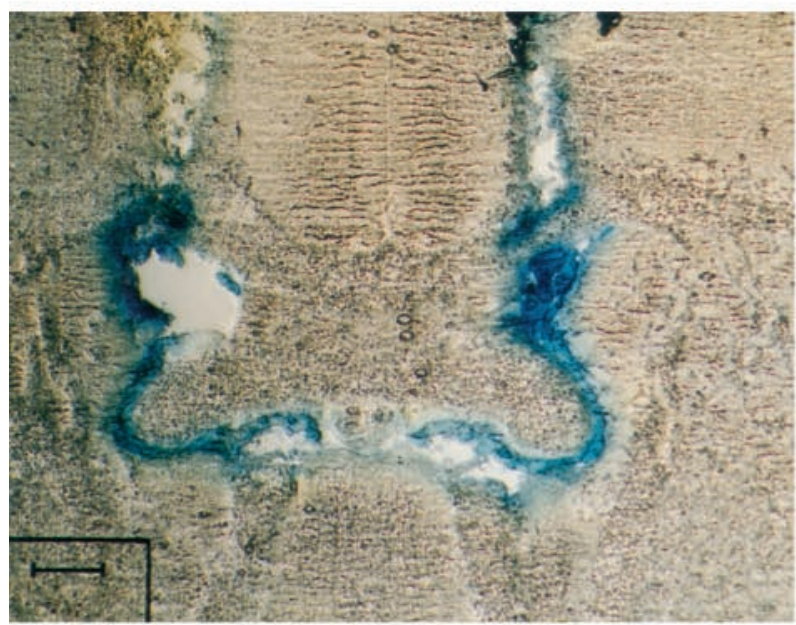

\section{i.c.v.}

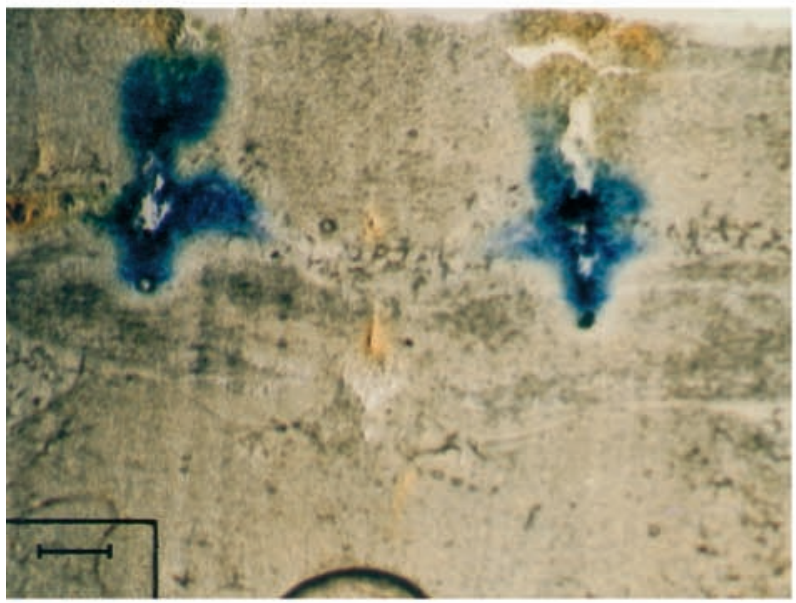

i.h.

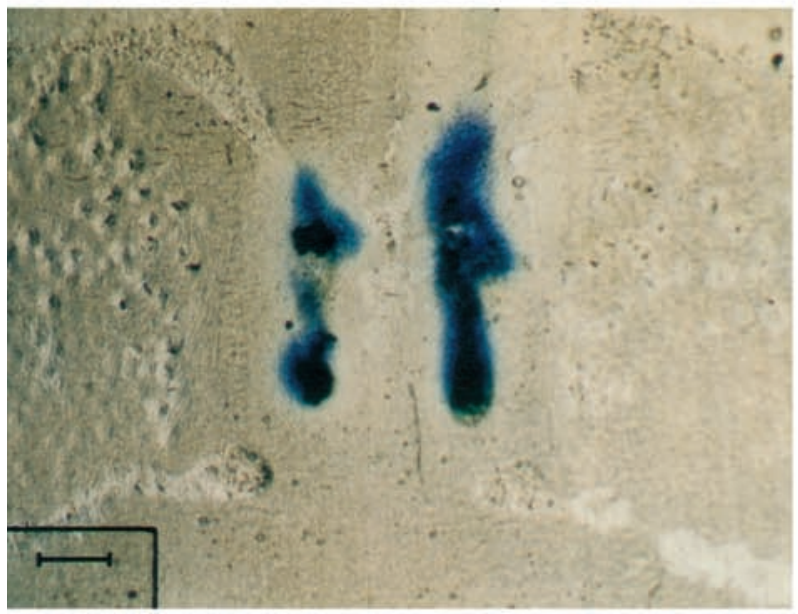

b
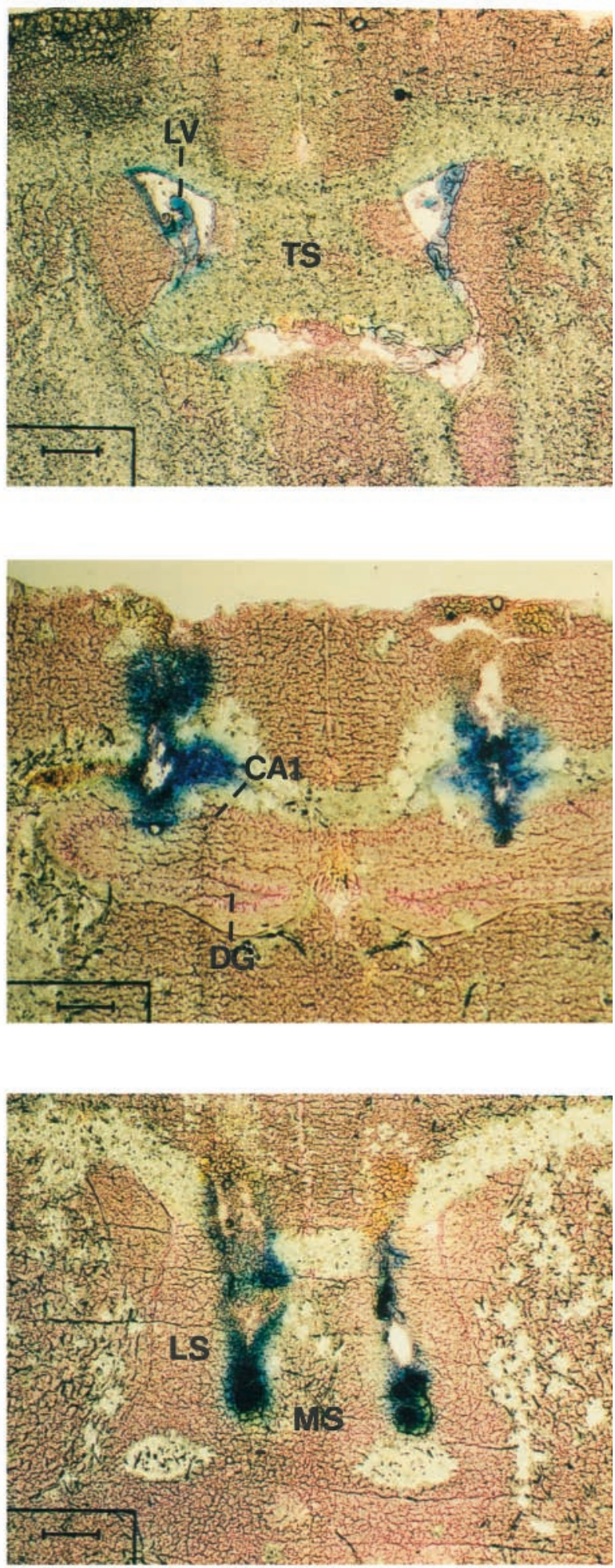

i.s.

Figure 1. Anatomical localization of the injection sites for CRF receptor agonists and antagonists. Native brain sections of mice injected with methylene blue $(a)$ and sections counterstained with nuclear fast red $(b)$. Scale bar, $400 \mu \mathrm{m}$. i.c.v., Intracerebroventricular; DG, dentate gyrus; CA1, hippocampal subfield; LS, lateral septum; LV, lateral ventricle; MS, medial septum; TS, trigonal septal nucleus. 
Garcia and Jaffard, 1996) and the enhancement of anxious behaviors (Menard and Treit, 1996).

\section{MATERIALS AND METHODS}

Animals. Nine-week old male BALB/c mice (Charles River, Sultzfeld, Germany) were individually housed in macrolon cages according to the recommendations of the Society for Laboratory Animal Science (Germany). All experiments were performed in accordance with the European Council Directive (86/609/EEC) with the permission of the Animal Protection Law enforced by the District Government of Braunschweig, State of Lower Saxony, Germany, which is in full agreement with the American Psychological Association ethical guidelines.

Peptide synthesis. All peptides were synthesized with the Fmoc strategy on solid phase, and for the synthesis of the cyclized CRF analog astressin, the amino acid derivative Fmoc-L-Glu(OAll)-OH was used (Rühmann et al., 1996, 1998).

Cannulation. Double cannulae were implanted $3 \mathrm{~d}$ before the experiments under $1.2 \%$ Avertin anesthesia $(0.4 \mathrm{ml}$ per mouse) and affixed to the skull by dental cement. The cannulae (Plastic 1) consisted of a double-guided cannula, dummy, and cap. The cannulae were placed into both lateral brain ventricles, anteroposterior (AP) $-0.5 \mathrm{~mm}$, lateral 1 $\mathrm{mm}$, depth $2 \mathrm{~mm}$, in the dorsal hippocampus, AP $-1.5 \mathrm{~mm}$, lateral $1 \mathrm{~mm}$, depth $2 \mathrm{~mm}$, or in the lateral intermediate septal area, AP $+1 \mathrm{~mm}$, lateral $0.5 \mathrm{~mm}$, depth $3 \mathrm{~mm}$ (see Fig. 1a) (Franklin and Paxinos, 1997). Before injection, mice were exposed to a light isofluran anesthesia, the cap and the dummy were removed, and peptide solutions were delivered through an injector linked by plastic tubing to two Hamilton microsyringes. The CRF receptor agonists and antagonists were injected 5 and $15 \mathrm{~min}$, respectively, before training, unless specified otherwise. Combined treatments were performed by injecting the antagonists 10 min before human/ rat $\mathrm{CRF}(\mathrm{h} / \mathrm{rCRF})$, which took place $5 \mathrm{~min}$ before training. All peptide stock solutions were prepared in $10 \mathrm{~mm}$ acetic acid. Final dilutions in twofold-concentrated artificial CSF (aCSF), $\mathrm{pH}$ 8.5, were prepared immediately before the experiments. The final $\mathrm{pH}$ of the peptide solutions was 7.4. Vehicle solutions were prepared by diluting $10 \mathrm{~mm}$ acetic acid in $\mathrm{aCSF}$ in an identical manner. The peptides were administered bilaterally by a microinjector (CMA/Microdialysis) over a $15 \mathrm{sec}$ period, so that a volume of $0.25 \mu \mathrm{l}$ was injected in each side. The volumes for local injections were selected on the basis of a histological analysis after methylene blue injections. Volumes sufficient to cover the whole area of interest (revealed by dye diffusion) were selected. The cannula placement was verified for each mouse by histological examination of the brains after methylene blue injection $(0.25 \mu \mathrm{l}$ per site) (see Fig. $1 b)$, and only the data obtained from mice with correctly inserted cannulae were included in statistical analysis. The number of mice per group was 7-13.

Amino acid analysis. After the end of animal treatments, aliquots of peptide solutions were subjected to amino acid analysis performed by hydrolysis with $6 \mathrm{M} \mathrm{HCl}$ in the presence of norvaline as internal standard to determine the exact peptide concentration of the injection solutions.

Fear conditioning. Context- and tone-dependent fear conditioning was performed as described previously (Stiedl and Spiess, 1997; Radulovic et al., 1998b). Briefly, training consisted of exposure of the mice to a conditioning context ( $3 \mathrm{~min})$ followed by a tone $(30 \mathrm{sec}, 10 \mathrm{kHz})$ and an electric footshock $(2 \mathrm{sec}, 0.7 \mathrm{~mA}$, constant current). The contextual memory test was performed $24 \mathrm{hr}$ later by re-exposing the mice to the conditioning context for $3 \mathrm{~min}$. Subsequently, the mice were placed in a novel context $(3 \mathrm{~min})$ and re-exposed to the tone $(3 \mathrm{~min})$. Freezing, defined as a lack of movement except for heart beat and respiration, was recorded in $10 \mathrm{sec}$ intervals simultaneously by two observers and was used as an index of fear. Locomotor activities and the percentage of the explored area were automatically detected by an infrared beam system and analyzed by a software developed in collaboration with TSE (Bad Homburg, Germany).

Immobilization stress. An acute immobilization stress of mice consisted of taping their limbs to a Plexiglas surface for $1 \mathrm{hr}$ (Smith et al., 1995).

Elevated plus-maze. Anxiety-related behavior was investigated using the plus-maze test (Radulovic et al., 1998c). The behavior of mice was recorded by a video camera connected to a PC computer and analyzed by TSE software (VideoMot 2). The time spent, distance crossed, and number of entries in the open arms, closed arms, and center were recorded. a Context
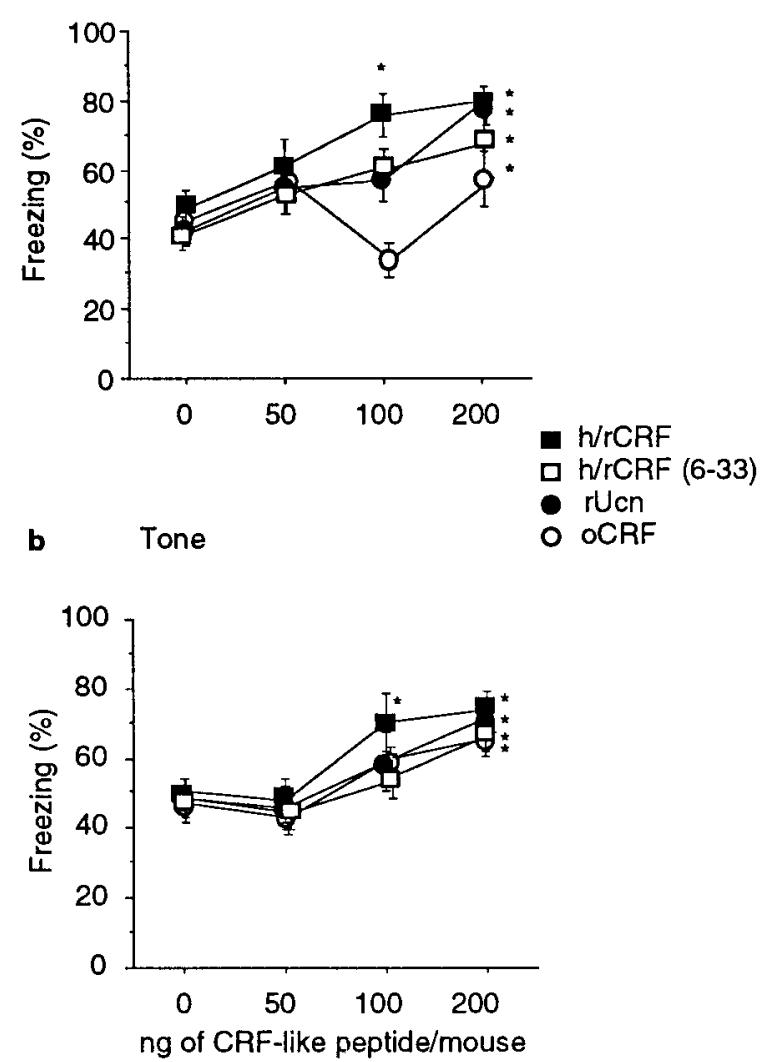

Figure 2. Dose-dependent effects of CRF-like peptides. Mice were injected intracerebroventricularly with $\mathrm{h} / \mathrm{rCRF}, \mathrm{h} / \mathrm{r} \mathrm{CRF}(6-33), \mathrm{rUcn}$, and oCRF 5 min before training. Context-dependent $(a)$ and tone-dependent (b) fear conditioning were determined $24 \mathrm{hr}$ later. Statistically significant differences: ${ }^{*} p<0.01$ versus aCSF.

\section{RESULTS}

\section{CRF-like peptides modulate fear conditioning in a brain region-specific manner}

In our initial experiments, the dose-dependent effect of several CRF-like peptides on fear conditioning was established by intracerebroventricular injection (see Fig. $2 a$ ) of BALB/c mice with $\mathrm{h} / \mathrm{rCRF}$, rat urocortin ( $\mathrm{rUcn}$ ), ovine CRF (oCRF), or the CRFbinding protein ligand $\mathrm{h} / \mathrm{rCRF}(6-33)$. Statistical analysis (twoway ANOVA followed by the Bonferonni-Dunn test) revealed that $\mathrm{h} / \mathrm{r}$ CRF, h/r CRF (6-33), rUcn, and oCRF dosedependently enhanced fear conditioning to both context, $F_{(12,103)}=5.158, p<0.001$ (Fig. $\left.1 a\right)$ and tone, $F_{(12,103)}=5.365$, $p<0.001$ (Fig. 2b). The strongest effect was observed after intracerebroventricular injection of $\mathrm{h} / \mathrm{rCRF}$. The lowest doses of CRF-like peptides per mouse that produced significant enhancement of conditioning to context and tone were $100 \mathrm{ng}$ (20 pmol) h/rCRF, $200 \mathrm{ng}$ (40 pmol) rUcn, $200 \mathrm{ng}$ (40 pmol) oCRF, and 200 $\mathrm{ng}(60 \mathrm{pmol}) \mathrm{h} / \mathrm{rCRF}(6-33)$. The locomotor activities and the activity burst in response to the shock of mice injected with CRF-like peptides did not differ from the values of control mice injected with aCSF (data not shown). Similarly, all CRF-like peptides enhanced acquisition of context-dependent $\left(F_{(4,32)}=\right.$ $10.795, p<0.001)$ and tone-dependent fear $\left(F_{(4,32)}=9.881, p<\right.$ 0.001) (Fig. 3a), after intrahippocampal (i.h.) injection. Enhancement of freezing by i.h. injection of $\mathrm{h} / \mathrm{rCRF}$ was demonstrated only for fear-conditioned mice, but not for mice receiving peptide 


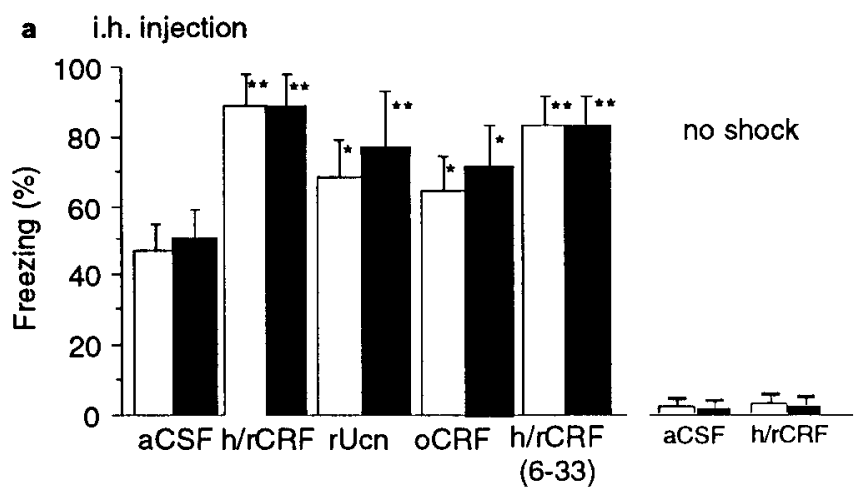

c Intracortical injection

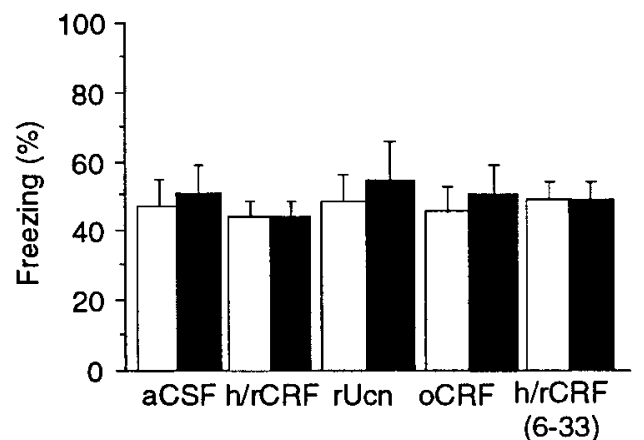

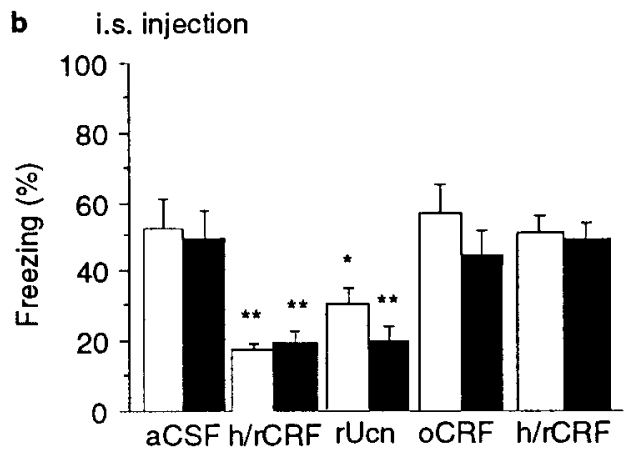

(6-33)

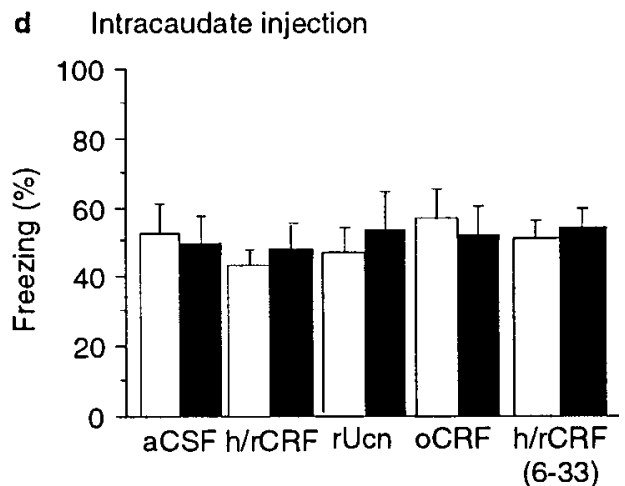

Tone

Figure 3. Region-specific effects of CRF-like peptides. Context- and tone-dependent fear conditioning after i.h. ( $a$ ), i.s. (b), intracortical (c), or intracaudate $(e)$ injection of 20 pmol peptide per mouse. Additional mice subjected to i.h. treatment but without receiving a shock (no shock) were used to test whether i.h. injection of h/rCRF produced immobility or place aversion $(a)$. Statistically significant differences: ${ }^{*} p<0.01$ versus aCSF; ${ }^{* *} p<0.001$ versus aCSF.

without a shock (Fig. 2a), indicating that enhanced freezing was not caused by effects of $\mathrm{h} / \mathrm{rCRF}$ on locomotor activity (Sutton et al., 1982) or place aversion (Cador et al., 1992). In contrast, injection of $\mathrm{h} / \mathrm{rCRF}$ or Ucn into the lateral intermediate septum (i.s.) significantly impaired context-dependent $\left(F_{(4,32)}=15.388\right.$, $p<0.001)$ and tone-dependent fear conditioning $\left(F_{(4,32)}=\right.$ 14.256, $p<0.001$ ) (Fig. 3b). h/rCRF was more effective than Ucn in modulating fear conditioning, whereas oCRF and h/r CRF(633) did not affect fear conditioning after i.s. injection. Injection of CRF-like peptides into the parietal somatosensory cortex and striatum, brain regions adjacent to the hippocampus and septum, respectively, did not produce any significant effects on contextand tone-dependent fear conditioning (Fig. 3c,d).

\section{Region-specific modulation of fear conditioning by $h /$ rCRF is dose dependent}

Subsequent experiments demonstrated that i.h. administration of $\mathrm{h} / \mathrm{rCRF}$ enhanced context-dependent $\left(F_{(3,35)}=9.726, p<0.001\right)$ and tone-dependent fear $\left(F_{(3,35)}=9.456, p<0.001\right)$ (Fig. $\left.3 a\right)$, whereas i.s. administration of $\mathrm{h} / \mathrm{rCRF}$ impaired context-dependent $\left(F_{(3,31)}=8.120, p<0.001\right)$ (Fig. $\left.4 a\right)$ and tone-dependent fear $\left(F_{(3,31)}=7.724, p<0.001\right)$ (Fig. $\left.4 b\right)$ in a dose-dependent manner. The minimally required dose for modulation of fear conditioning after local administration of $\mathrm{h} / \mathrm{rCRF}$ was $25 \mathrm{ng}$ per injection site [a total of $50 \mathrm{ng}(10 \mathrm{pmol})$ per mouse], a dose ineffective after intracerebroventricular injection of $\mathrm{h} / \mathrm{rCRF}$. The dose required to produce a maximal effect after i.h. injection (to $100 \%$ of values observed in mice injected with aCSF alone, in the absence of peptide) was $50 \mathrm{ng} \mathrm{h/rCRF} \mathrm{per} \mathrm{injection} \mathrm{site} \mathrm{(Fig.} 4 a, b$ ). The same dose applied intracerebroventricularly produced an enhancement of $55 \%$ of control values (Fig. $2 a, b$ ). These results excluded the possibility that the effects observed after i.h. injection of $h / r C R F$ were caused by peptide leakage into the lateral brain ventricles.

\section{Modulation of fear conditioning by $h / r C R F$ is restricted to a small time window}

To investigate the time window that is susceptible to the modulation of memory consolidation by $\mathrm{h} / \mathrm{rCRF}$, mice were given i.h. or i.s. injections with $\mathrm{h} / \mathrm{rCRF}$ at different time points in relation to training. In addition to the effects observed previously when $\mathrm{h} / \mathrm{rCRF}$ was injected before the training, i.h. administration of $\mathrm{h} / \mathrm{rCRF}$ immediately after the training also enhanced acquisition of context-dependent $\left(F_{(5,48)}=9.568, p<0.001\right)$ and tonedependent fear $\left(F_{(5,48)}=9.344, p<0.001\right)$ (Fig. 5a). An h/rCRF i.h. injection $1 \mathrm{hr}$ after training did not exhibit any significant effect. An i.s. injection of $\mathrm{h} / \mathrm{rCRF}$ differentially affected acquisition of context-dependent $\left(F_{(5,46)}=9.133, p<0.001\right)$ and tonedependent fear conditioning $\left(F_{(5,46)}=7.95, p<0.001\right)$ (Fig. $\left.5 b\right)$. Context-dependent fear was impaired by i.s. injection of $\mathrm{h} / \mathrm{rCRF}$ before and immediately after the training, whereas injection $1 \mathrm{hr}$ after the training was ineffective. Tone-dependent fear was impaired only when i.s. injection of $\mathrm{h} / \mathrm{rCRF}$ was given before the training. 
a i.h. injection
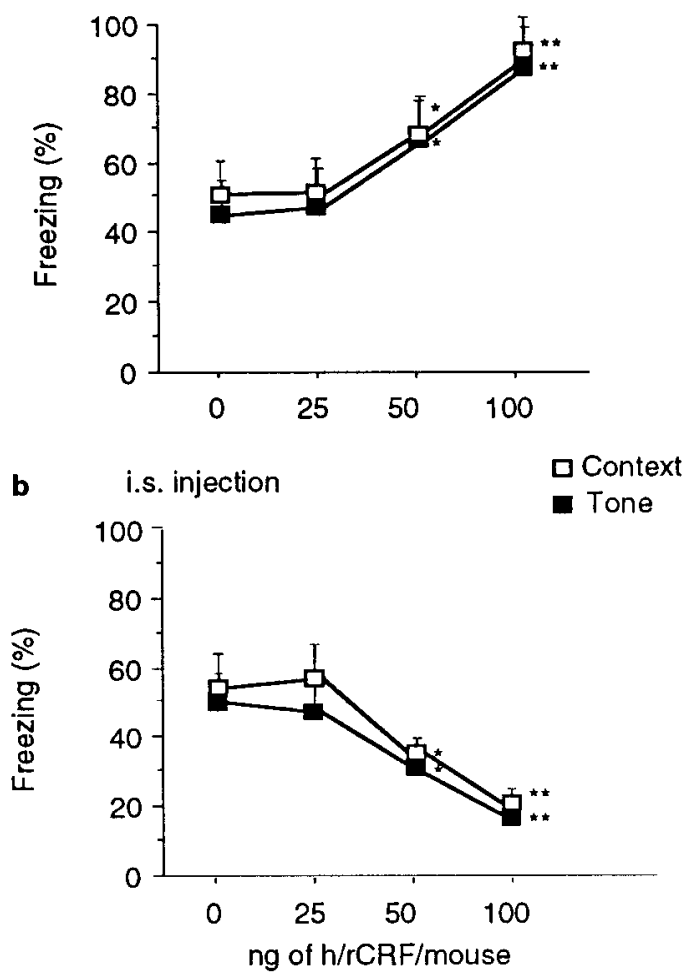

Figure 4. Dose-dependent effect of $\mathrm{h} / \mathrm{rCRF}$ injected i.h. or i.s. Contextand tone-dependent fear conditioning of mice injected i.h. $(a)$ or i.s. (b) $5 \mathrm{~min}$ before training was determined $24 \mathrm{hr}$ later. Statistically significant differences: ${ }^{*} p<0.01$ versus aCSF; ${ }^{*} p<0.001$ versus aCSF.

\section{Enhancement of conditioned fear after i.h. injection of CRF is mediated by CRFR1, whereas impairment of conditioned fear after i.s. injection is mediated by CRFR2}

The enhancement of fear conditioning after i.h. injection of $\mathrm{h} / \mathrm{rCRF}$ was completely blocked by previous administration of astressin but not antisauvagine-30 (anti-Svg-30) (Fig. 6a), a peptidic antagonist recently developed in our laboratory (Rühmann et al., 1998). In contrast to astressin, a nonselective antagonist for both CRFR1 and 2, anti-Svg-30 was demonstrated to block preferentially CRFR2 (Rühmann et al., 1998). Both astressin and anti-Svg-30 blocked the memory-impairing effects of i.s. injection of $\mathrm{h} / \mathrm{rCRF}$ (Fig. 6b). Administration of the CRF receptor antagonists astressin and anti-Svg-30 alone into the hippocampus did not affect fear conditioning, whereas their i.s. injection significantly enhanced fear conditioning to context $\left(F_{(5,42)}=12.089\right.$, $p<0.001)$ and tone $\left(F_{(5,42)}=11.664, p<0.001\right)$. Thus, these antagonists exhibited an effect opposite to the one of $\mathrm{h} / \mathrm{rCRF}$ and suggested that fear conditioning was tonically impaired by septal CRFR2 but not by hippocampal CRFR1.

\section{$\mathrm{h} / \mathrm{rCRF}$ induces anxious behavior through septal CRFR2 but not hippocampal CRFR1}

The dose of $\mathrm{h} / \mathrm{rCRF}$ modulating fear conditioning did not affect plus-maze behavior (Fig. 7), as evaluated by time spent, number of entries, and distance crossed on the open and closed arms of an elevated plus-maze. However, i.s. injection of $500 \mathrm{ng} \mathrm{h} / \mathrm{rCRF}$ per mouse significantly reduced the time spent $\left(F_{(4,45)}=4.32, p<\right.$ $0.01)$ (Fig. $7 a)$ and the number of entries $\left(F_{(4,45)}=4.11, p<0.01\right)$ (Fig. $7 b$ ) on the open arms without affecting locomotor activity (data not shown), as revealed by the total distance crossed in 5 min. Decreased time on the open arms and decreased number of open arm entries are believed to reflect anxious behavior (Dunn and Berridge, 1990; De Souza, 1995). Astressin and anti-Svg-30 applied by i.s. injection completely antagonized anxiety induced by i.s. injection of $\mathrm{h} / \mathrm{rCRF}$ (Fig. $7 a, b$ ), without affecting baseline anxiety levels.

\section{h/rCRF mediates stress-induced enhancement of fear conditioning through hippocampal CRFR1 and stress- induced anxiety through septal CRFR2}

The role of CRF in stress-induced changes of fear conditioning and anxiety was investigated to establish whether the effects observed after pharmacological manipulations could be reproduced by stressful events that are known to activate the brain CRF system (Dunn and Berridge, 1990). In mice subjected to $1 \mathrm{hr}$ immobilization stress, fear conditioning to context $\left(\left(F_{3,40}=\right.\right.$ 7.134, $p<0.01)$ and tone $\left(F_{3,40}=6.795, p<0.01\right)$ was significantly increased $3 \mathrm{hr}$ after termination of the stress when compared with nonstressed controls (Fig. 8a). In view of the previous findings showing memory enhancement after i.h. injection of $h / r$ $\mathrm{CRF}$, the ability of i.h. injection of astressin to prevent stressinduced increase of fear conditioning was tested. Astressin completely antagonized stress-induced enhancement of conditioned fear when given by i.h. injection either before the immobilization stress or before the training (Fig. 8b).

The same type of stressor was used to investigate the role of endogenous CRF in stress-induced anxiety. One hour immobilization produced anxious behavior when applied $30 \mathrm{~min}$ before the elevated plus-maze test (Fig. 9a,b), as revealed by reduced time spent and number of entries on the open arms of the maze $\left(F_{(3,37)}=6.323, p<0.01\right)$. Astressin and anti-SVG-30 completely prevented stress-induced anxiety when given by i.s. injection (Fig. $9 c, d$ ) but not by i.h. injection (data not shown) before the immobilization stress.

\section{DISCUSSION}

\section{CRF-like peptides modulate fear conditioning in a region-specific manner}

In the present study, it was demonstrated that intracerebroventricular injection of the peptides $\mathrm{h} / \mathrm{rCRF}$, Ucn, oCRF, and $\mathrm{h} / \mathrm{rCRF}$ (6-33) dose-dependently enhanced context- and tonedependent fear conditioning. However, local injections of these peptides, with doses lower than those injected into the ventricles, revealed that $\mathrm{h} / \mathrm{rCRF}$ enhanced fear conditioning after i.h. injection and impaired it after i.s. injection in a dose-dependent manner. Control experiments demonstrated that these effects were specifically mediated through the dorsal hippocampus and lateral intermediate septum but not through the neighboring brain areas or lateral ventricles.

The observation that $\mathrm{h} / \mathrm{rCRF}$ was more effective than Ucn in enhancing or impairing fear conditioning was surprising in view of the assumption that Ucn may be the putative ligand for CRFR2 and the finding that Ucn binds under defined conditions with higher affinity than $\mathrm{h} / \mathrm{rCRF}$ to both CRFR1 and CRFR2 (Vaughan et al., 1995). Thus, it appears that the in vivo interactions of $\mathrm{h} / \mathrm{rCRF}$ and Ucn with their receptors differed from the ones in vitro. Such difference could be explained, at least in part, by the partial agonism of rUcn toward CRFR1 (A. Rühmann and J. Spiess, unpublished results). The ability of the CRF-BP ligand $\mathrm{h} / \mathrm{rCRF}(6-33)$ to enhance fear conditioning after intracerebroventricular injection was in agreement with previous studies 

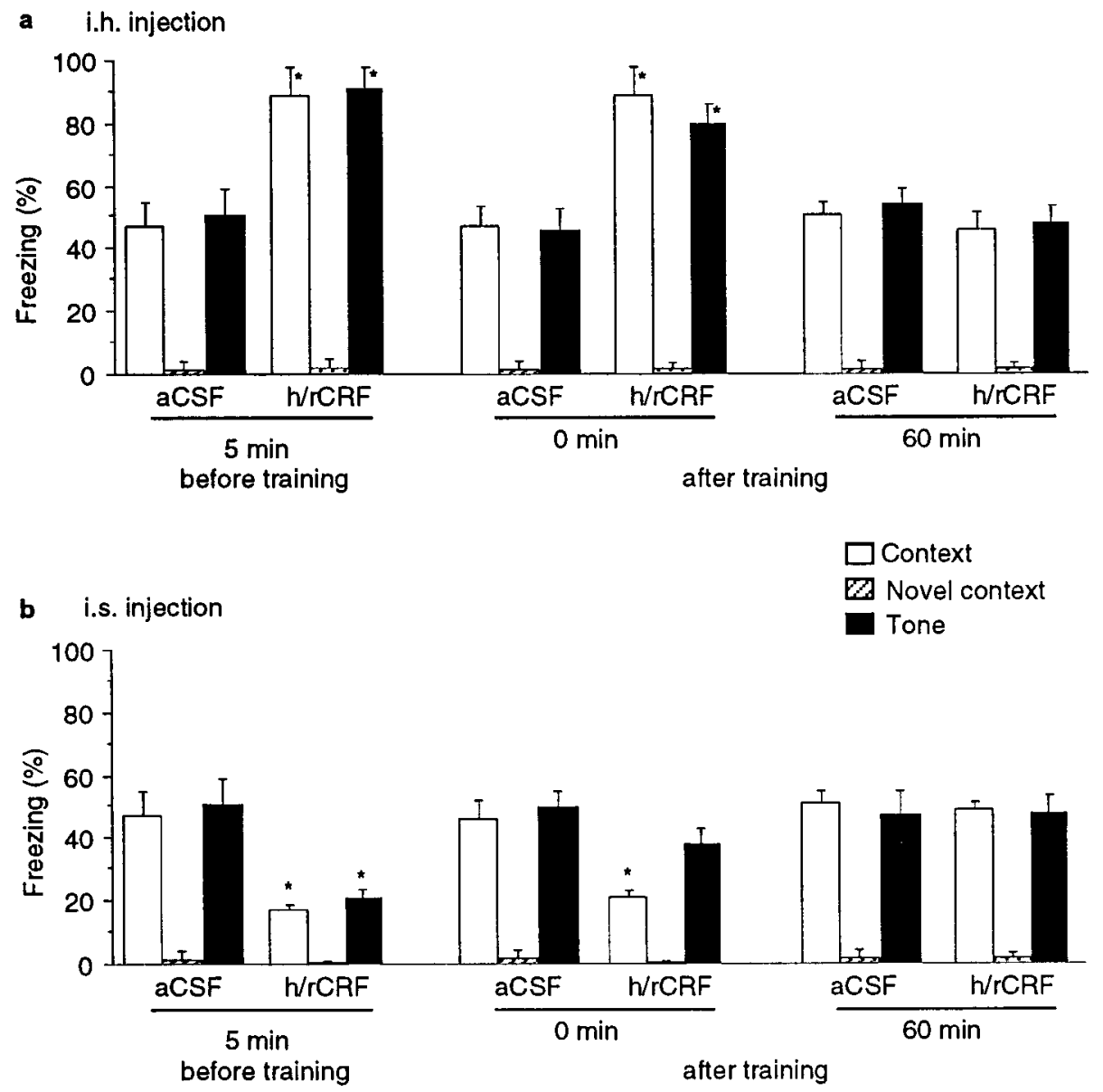

Figure 5. Injections of $\mathrm{h} / \mathrm{rCRF}$ before and after training. h/rCRF (20 pmol per mouse) was injected i.h. $(a)$ and i.s. $(b)$ before and after training as indicated. Freezing to context, novel context, and tone is presented. Statistically significant differences: ${ }^{*} p<0.001$ versus aCSF.
(Behan et al., 1995). The results of the i.h. injections demonstrated that this effect was mediated by the dorsal hippocampus. The inefficiency of $\mathrm{h} / \mathrm{rCRF}(6-33)$ to affect fear conditioning after i.s. injection was consistent with the low abundance of CRF-BP in the septal area (Potter et al., 1992). oCRF, a peptide that binds with high affinity to CRFR1 but poorly to CRFR2, was effective in modulating fear conditioning only after i.h. but not after i.s. injection. These results suggested that impairment of fear conditioning by $\mathrm{h} / \mathrm{rCRF}$ through the lateral septal area may be mediated by the recently identified CRFR2. In agreement with this observation, high levels of CRFR $2 \alpha$ mRNA but not CRFR1 mRNA (Chalmers et al., 1995) or CRFR1 protein (Radulovic et al., 1998a) were found in the lateral intermediate septum.

\section{CRF enhances fear conditioning through CRFR1 and impairs it through CRFR2}

The receptor specificity of the CRF effects on fear conditioning was demonstrated for the first time in the present study by using two CRFR antagonists: the nonselective antagonist astressin and the selective CRFR2 antagonist anti-Svg-30. Because the enhancement of fear conditioning by i.h. injection of $\mathrm{h} / \mathrm{rCRF}$ was prevented by astressin but not anti-Svg- 30, it was concluded that this effect was mediated by CRFR1. In contrast, the impairment of fear conditioning observed after i.s. application of $\mathrm{h} / \mathrm{rCRF}$ was mediated by CRFR2, as indicated by the ability of both astressin and anti-Svg-30 to block this effect. The ability of anti-Svg-30, originally developed as a CRFR $2 \beta$ antagonist, to prevent the behavioral effect of $\mathrm{h} / \mathrm{rCRF}$ was consistent with previous data demonstrating that the CRFR2 $\alpha$ and $\beta$ splice variants share similar ligand-binding properties (Donaldson et al., 1996).
The effects of CRF on fear conditioning are specific for memory consolidation

Modulation of conditioned fear observed in the present experiments was specific for learning and not performance, as demonstrated by the efficiency of $\mathrm{h} / \mathrm{rCRF}$ to modulate the acquisition of the fear response when injected immediately after the training, but not at a later time point. The effect of post-training i.h. injection of $\mathrm{h} / \mathrm{rCRF}$ to increase fear conditioning excluded the possibility that the observed effect was caused by attentional, motivational, or arousal effects. The specific action of CRF on learning was also supported by the observation that CRF-injected mice exhibited strong freezing to the context and tone used as conditioned stimuli, but this fear response did not generalize to a novel context.

After post-training i.s. injections of $\mathrm{h} / \mathrm{rCRF}$, a dissociation of CRFR2-mediated effects on context and tone was observed. In view of the inability of $\mathrm{h} / \mathrm{rCRF}$ to impair conditioning to tone, it was suggested that stimulation of CRFR2 had to occur before or during training to affect tone-dependent fear conditioning. This finding was consistent with the tonic role of septal CRFR2, as demonstrated by the ability of the CRFR antagonists astressin and anti-Svg-30 to produce an opposite effect when compared with $\mathrm{h} / \mathrm{rCRF}$. The impairment of contextual fear conditioning by i.s. injection of $\mathrm{h} / \mathrm{rCRF}$ after the training was probably the result of longer processing of contextual stimuli (Rudy and Morledge, 1994; O. Stiedl and J. Spiess, unpublished observations), which may render this form of conditioning susceptible to modulation over a longer time.

The results from this study demonstrated that learning of 
a i.h. injection

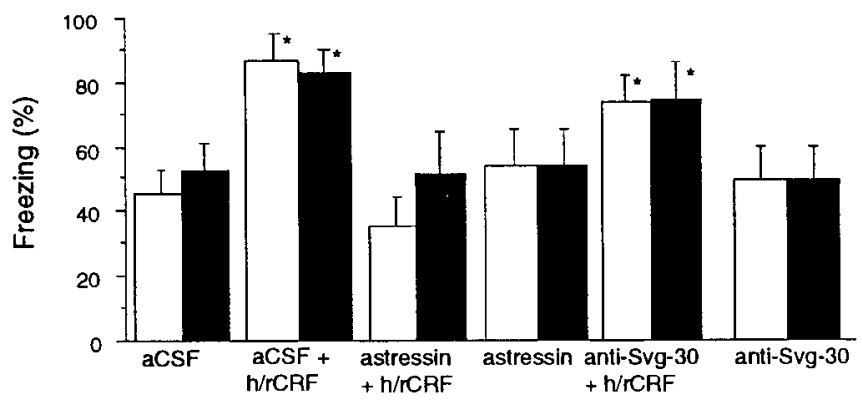

b i.s. injection

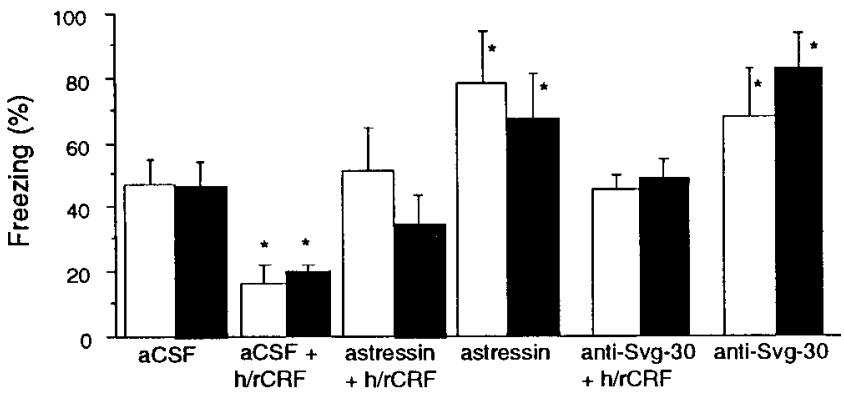

Context

Figure 6. Receptor-specificity of the effect of $\mathrm{h} / \mathrm{rCRF}$ on fear conditioning. The CRFR antagonists astressin [300 $\mathrm{ng}(85 \mathrm{pmol})$ per mouse] or anti-Svg-30 [400 ng (100 pmol) per mouse] were injected $10 \mathrm{~min}$ before i.h. (a) or i.s. (b) administration of $\mathrm{h} / \mathrm{rCRF}$ [100 ng ( $20 \mathrm{pmol})$ per mouse], which was applied 5 min before training. Statistically significant differences: ${ }^{*} p<0.001$ versus aCSF.

aversive stimuli after classic fear conditioning is profoundly and differentially modulated by the hippocampal CRFR1 and septal CRFR2 systems. Numerous studies, using lesioning (Kim and Fanselow, 1992; Phillips and LeDoux, 1992) and genetic (Aiba et al., 1994; Tsien et al., 1996) strategies, indicated that the hippocampus plays a crucial role in context-dependent fear conditioning. Thus, enhancement of context-dependent fear, observed after injection of CRF-like peptides into the CA1 area, was consistent with this view. However, enhancement of tonedependent fear, generally believed to be mediated by different neuronal circuits, contrasted with the common view that the hippocampal formation does not play a role in acquisition of tone-dependent fear. It should be mentioned, however, that a recent study reported impairment of tone-dependent fear conditioning after neurotoxic and electrolytic lesions of the dorsal hippocampus (Maren et al., 1997), a region used for CRF-like peptide injections in our experiments. Enhanced associative learning of tone-dependent fear through hippocampal CRFR1 could result from activation of hippocampal pathways to the amygdala (Henke, 1990), a brain region identified as being crucial for acquisition of fear responses.

The impairment of fear conditioning through CRFR2, observed after i.s. injection of CRF, was consistent with the inhibition of fear responses to contextual and explicit cues observed after stimulation of the lateral septum (Thomas and Yadin, 1980; Yadin and Thomas, 1981; Garcia and Jaffard, 1996).

\section{Septal CRFR2 mediates CRF-induced anxiety}

The dose of $\mathrm{h} / \mathrm{rCRF}$ required to produce maximal enhancement or impairment of fear conditioning did not affect anxiety. In agreement with previous findings (Behan et al., 1995), the dose of $\mathrm{h} / \mathrm{rCRF}$ required for induction of anxiety-related behavior was higher than the dose that modulated learning. The inefficiency of CRFR antagonists alone to affect the behavior of mice in the plus-maze suggested that hippocampal and septal CRFR did not contribute to a significant extent to the tonic regulation of anxiety by CRF. It appears, therefore, that decreased anxious responses recently observed with CRFR1-deficient mice (Smith et al., 1998; Timpl et al., 1998) could be caused by CRFR1 deficiency in brain areas other than the hippocampus. Stress-induced anxious behavior was fully prevented by i.s. injection of anti-Svg-30. Thus, an

Figure 7. Anxiogenic action of $\mathrm{h} / \mathrm{rCRF}$ in the lateral intermediate septum. The time spent $(a)$ and number of entries $(b)$ on the open arms of an elevated plus-maze were determined $30 \mathrm{~min}$ after $\mathrm{h} / \mathrm{rCRF}$ injection. The antagonists astressin (85 pmol per mouse) and anti-Svg-30 (100 pmol per mouse) were injected i.s. 10 min before the application of $\mathrm{h} / \mathrm{rCRF}$ (500 ng per mouse), which was used $30 \mathrm{~min}$ before the plus-maze test. Statistically significant differences: ${ }^{*} p<$ 0.01 versus aCSF.

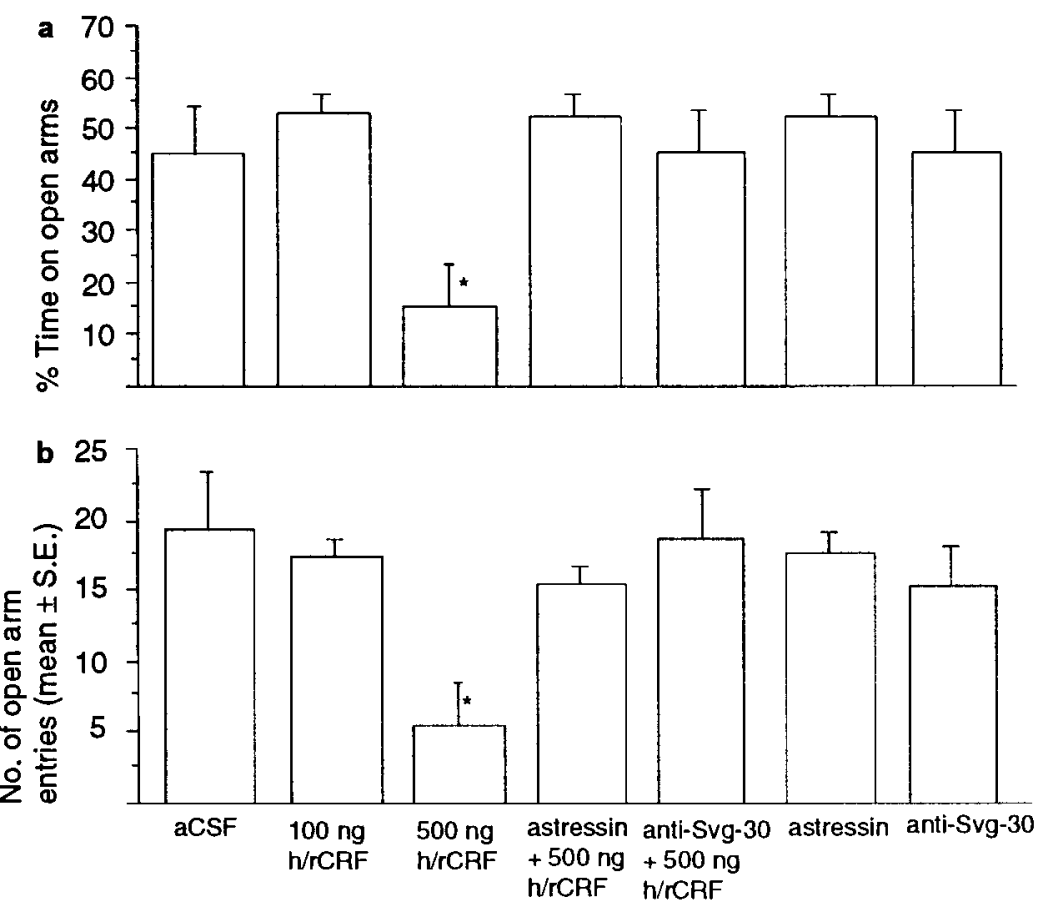



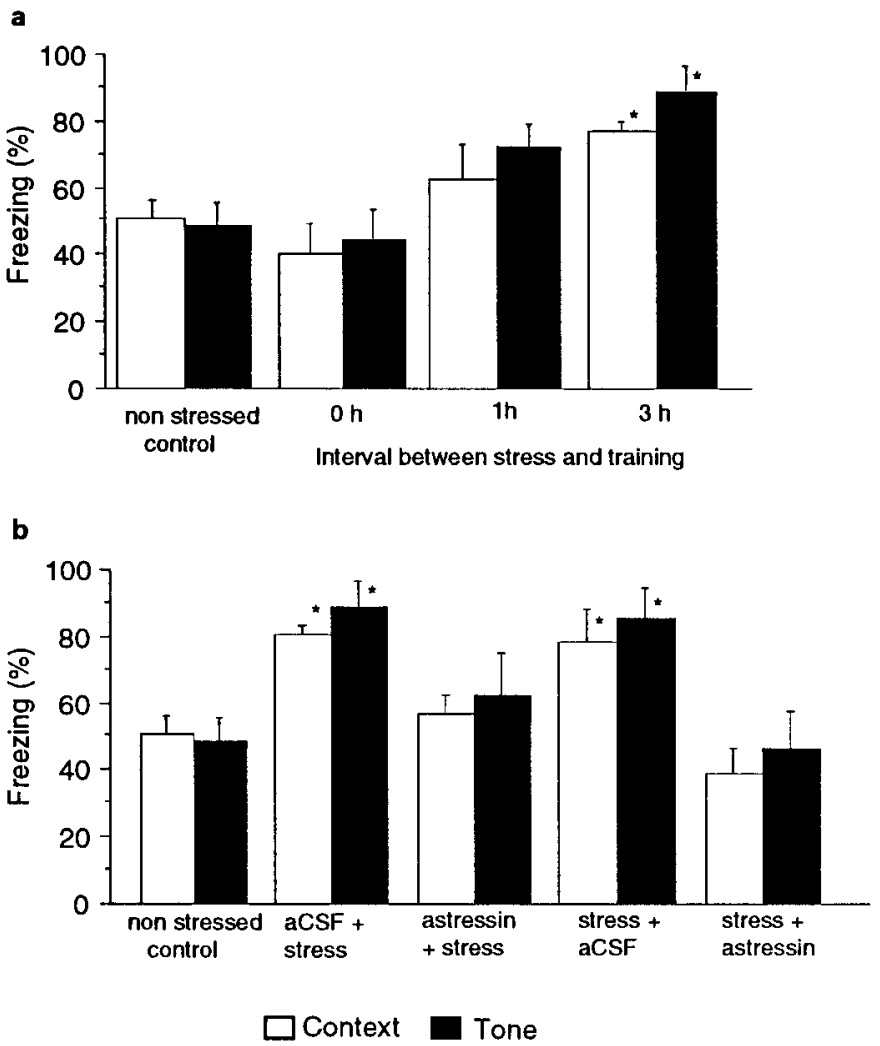

Figure 8. Stress-induced enhancement of fear conditioning through hippocampal CRFR1. $a$, In mice subjected for $1 \mathrm{hr}$ to immobilization and trained $3 \mathrm{hr}$ later, fear conditioning to context and tone was significantly enhanced $(p<0.01)$. $b$, This effect was fully antagonized by astressin injected i.h. ( 85 pmol per mouse) either immediately before immobilization stress (astressin + stress) or 15 min before the training (stress + astressin). Statistically significant differences: ${ }^{*} p<0.001$ versus nonstressed mice. additional novel role of septal CRFR2 was demonstrated in anxiety generated by pharmacological or stress-induced increase of CRF activity.

\section{Septal CRFR2 mediates stress-induced anxiety, whereas hippocampal CRFR1 mediates stress-induced enhancement of fear conditioning}

Exposure of mice to immobilization stress produced sequential changes in anxiety and learning, as shown by a transiently increased anxiety after $30 \mathrm{~min}$ that disappeared after $1 \mathrm{hr}$, followed by enhanced acquisition of conditioned fear after $3 \mathrm{hr}$. The stress-induced increase of anxiety and fear conditioning could be fully prevented by septal and hippocampal CRFR antagonists, respectively, which under nonstress conditions did not affect either behavior by themselves. Interestingly, astressin prevented the effects of stress when given by i.h. application before as well as 3 hr after immobilization, suggesting that hippocampal CRFR1 was activated biphasically, during stress and $3 \mathrm{hr}$ after termination of the stressful stimulus.These results, demonstrating potentiation of CRFR-mediated effects after stress, are consistent with increasing recent evidence suggesting that the glucocorticoid hormones lower the threshold for CRF actions in the limbic system (Schulkin et al., 1998). Consistently, the high density of glucocorticoid receptors and almost restricted distribution of mineralocorticoid receptors was demonstrated in the lateral septum and hippocampus (Reul and De Kloet, 1985). The different time course of stress-induced facilitation of anxious behavior and fear conditioning suggests that the CRF actions mediated through septal CRFR2 and hippocampal CRFR1 are differentially affected by stress. It is not clear whether the anxiety response is necessary for the subsequent enhancement of learning or whether these responses occur independently from each other.

The presented data indicate that the role of the endogenous CRF system in learning and anxiety strongly depends on the brain area, receptor type, and previous stressful experiences. The existence of two receptors, CRFR1 and CRFR2, mediating opposite effects on learning may appear paradoxical on the basis of a
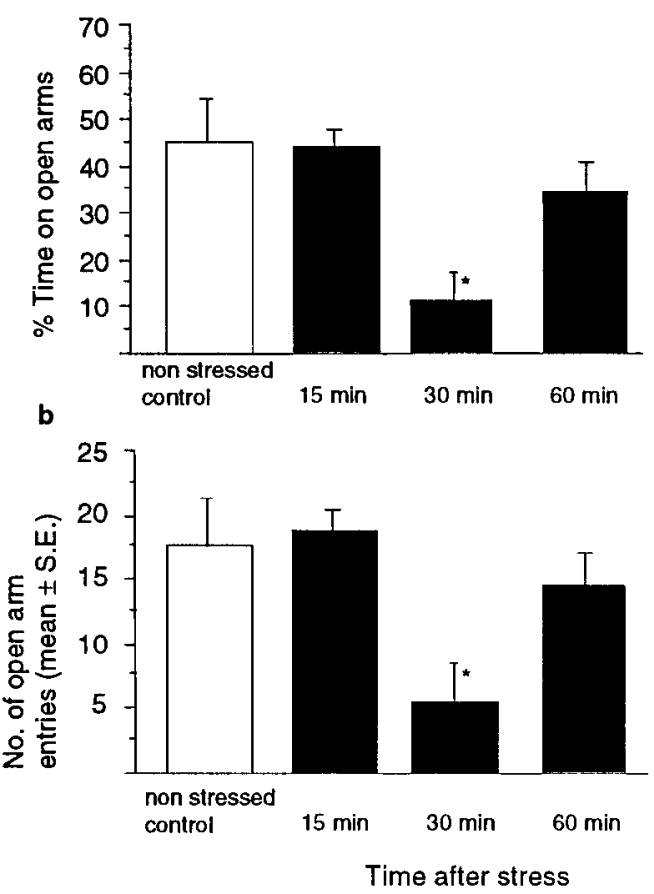

c

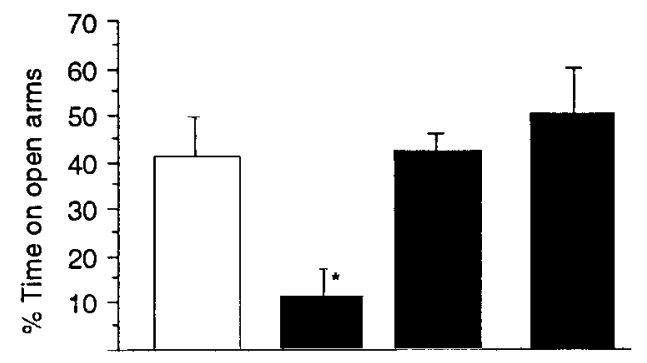

d

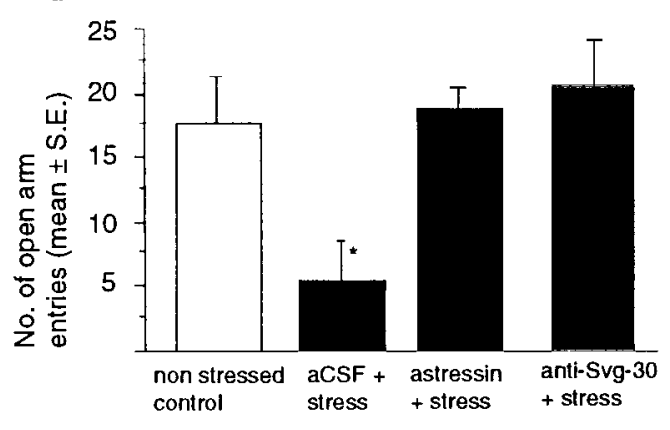

Figure 9. Stress-induced anxiety mediated through septal CRFR2. In mice subjected for $1 \mathrm{hr}$ to immobilization, the time spent $(a)$ and number of entries $(b)$ on the open arms of an elevated plusmaze were significantly reduced after $30 \mathrm{~min}$. CRFR antagonists astressin (85 pmol per mouse) and anti-Svg-30 (100 pmol per mouse) injected i.s. fully prevented the decrease of the time spent $(c)$ and number of entries $(d)$ on the open arms of the plusmaze observed $30 \mathrm{~min}$ after stress. Statistically significant differences: $* p<0.01$ versus nonstressed mice. 
pharmacological studies. However, impairment of learning through septal CRFR2 under baseline conditions and enhancement of learning through hippocampal CRFR1 after stress demonstrated that the brain CRF systems may subserve different roles in the processing of sensory information generated by stimuli of different biological significance. Thus the existence of two receptors mediating opposite effects under different conditions provides the CRF system with a high flexibility and a dynamic role in the plastic adaptation of the CNS to environmental challenge.

\section{REFERENCES}

Aiba A, Chen C, Herrup K, Rosenmund C, Stevens C F, Tonegawa (1994) Reduced hippocampal long-term potentiation and contextspecific deficit in associative learning in mGluR1 mutant mice. Cell 79:366-375.

Behan DP, Heinrichs SC, Troncoso JC, Liu XJ, Kawas CH, Ling N, De Souza EB (1995) Displacement of corticotropin releasing factor from its binding protein as a possible treatment for Alzheimer's disease. Nature 378:284-287.

Behan D, Khongsaly O, Ling N, De Souza EB (1996) Urocortin interaction with corticotropin-releasing factor (CRF) binding protein (CRFBP): a novel mechanism for elevating "free" CRF levels in human brain. Brain Res 725:263-267.

Cador M, Ahmed S H, Koob GF, Le Moal M, Stinus L (1992) Corticotropin-releasing factor induces a place aversion independent of its neuroendocrine role. Brain Res 597:304-309.

Chang CP, Pearse RV, O'Connell S, Rosenfeld MG (1993) Identification of a seven transmembrane helix receptor for corticotropinreleasing factor and sauvagine in mammalian brain. Neuron 11:1187-1195

Chalmers DT, Lovenberg TW, De Souza EB (1995) Localization of novel corticotropin-releasing factor receptor (CRF2) mRNA expression to specific subcortical nuclei in rat brain: comparison with CRF1 receptor mRNA expression. J Neurosci 15:6340-6350.

Chen R, Lewis KA, Perrin MH, Vale WW (1993) Expression cloning of a human corticotropin-releasing-factor receptor. Proc Natl Acad Sci USA 90:8967-8971.

Cummings S, Elde R, Ells J, Lindall A (1983) Corticotropin-releasing factor immunoreactivity is widely distributed within the central nervous system of the rat. J Neurosci 3:1355-1368.

Dautzenberg FM, Wille S, Lohmann R, Spiess J (1998) Mapping of the ligand-selective domain of Xenopus laevis CRF receptor: implications for the ligand-binding site. Proc Natl Acad Sci USA 95:4941-4946.

De Souza EB (1995) Corticotropin-releasing factor receptors: physiology, pharmacology, biochemistry and role in central nervous system and immune disorders. Psychoneuroendocrinology 20:789-819.

Diamant M, de Wied D (1993) Structure-related effects of CRF and CRF-derived peptides: dissociation of behavioral, endocrine and autonomic activity. Neuroendocrinology 57:1071-1081.

Donaldson CJ, Sutton SW, Perrin MH, Corrigan AZ, Lewis KA, Rivier J, Vaughan JM, Vale WW (1996) Cloning and characterization of human urocortin. Endocrinology 137:2167-2170.

Dunn AJ, Berridge CW (1990) Physiological and behavioral responses to corticotropin-releasing factor administration: is CRF a mediator of anxiety or stress responses? Brain Res Rev 15:71-100.

Franklin KBJ, Paxinos G (1997) The mouse brain in stereotaxic coordinates. San Diego: Academic.

Garcia R, Jaffard R (1996) Changes in synaptic excitability in the lateral septum associated with contextual and auditory fear conditioning in mice. Eur J Neurosci 8:809-815.

Heinrichs SC, Vale EA, Lapsansky J, Behan DP, Mcclure LV, Ling N, De Souza EB, Schulteis G (1997) Enhancement of performance in multiple learning tasks by corticotropin-releasing factor-binding protein ligand inhibitors. Peptides 18:711-716.

Henke PG (1990) Hippocampal pathway to the amygdala and stress ulcer development. Brain Res Bull 25:691-696.

Kim JJ, Fanselow MS (1992) Modality-specific retrograde amnesia of fear. Science 256:675-677.

Kishimoto T, Pearse RV, Lin CR, Rosenfeld MG (1995) A sauvagine/ corticotropin-releasing factor receptor expressed in heart and skeletal muscle. Proc Natl Acad Sci USA 92:1108-1112.
Koob G, Heinrichs SC, Menzaghi F, Pich EM, Britton KT (1994) Corticotropin releasing factor, stress and behavior. Semin Neurosci 6:221-229.

Koob GF, Bloom FE (1985) Corticotropin-releasing factor and behavior. Fed Proc 44:259-263.

Kozicz T, Yanaihara H, Arimura A (1998) Distribution of urocortin-like immunoreactivity in the central nervous system of the rat. J Comp Neurol 391:1-10.

Liang KC, Lee EHY (1988) Intra-amygdala injections of corticotropinreleasing factor facilitate inhibitory avoidance learning and reduce exploratory behavior in mice. Psychopharmacology 96:232-236.

Lovenberg TW, Liaw CW, Grigoriadis DE, Clevenger W, Chalmers DT, De Souza EB, Oltersdorf T (1995) Cloning and characterization of a functionally distinct corticotropin-releasing factor receptor subtype from rat brain. Proc Natl Acad Sci USA 92:836-840.

Maren S, Aharonov G, Fanselow MS (1997) Neurotoxic lesions of the dorsal hippocampus and Pavlovian fear conditioning in rats. Behav Brain Res 88:261-274.

Menard J, Treit D (1996) Lateral and medial septal lesions reduce anxiety in the plus-maze and probe-burying tests. Physiol Behav 60:845-853.

Olschowka JA, O’Donohue TL, Mueller GP, Jacobowitz DM (1982) The distribution of corticotropin releasing factor-like immunoreactive neurons in rat brain. Peptides 3:995-1015.

Perrin M, Donaldson C, Chen R, Blount A, Berggren T, Bilezikjian L, Sawchenko P, Vale W (1995) Identification of a second corticotropinreleasing factor receptor gene and characterization of a cDNA expressed in heart. Proc Natl Acad Sci USA 92:2969-2973.

Phillips RG, LeDoux JE (1992) Differential contribution of amygdala and hippocampus to cued and contextual fear conditioning. Behav Neurosci 106:274-285.

Potter E, Behan DP, Fischer WH, Linton EA, Lowry PJ, Vale WW (1991) Cloning and characterization of the cDNAs for human and rat corticotropin releasing factor-binding proteins. Nature 349:423-426.

Potter E, Behan DP, Linton EA, Lowry PJ, Sawchenko PE, Vale WW (1992) The central distribution of a corticotropin releasing factor (CRF)-binding protein predicts multiple sites and modes of action. Proc Natl Acad Sci USA 89:4192-4196.

Radulovic J, Sydow S, Spiess J (1998a) Characterization of native corticotropin-releasing factor receptor type 1 (CRFR1) in the rat and mouse central nervous system. J Neurosci Res 54:507-521.

Radulovic J, Kammermeier J, Spiess J (1998b) Relationship between FOS production and classical fear conditioning: effects of novelty, latent inhibition and unconditioned stimulus preexposure. $\mathrm{J}$ Neurosci 18:7452-7461.

Radulovic J, Kammermeier J, Spiess J (1998c) Generalization of fear responses in $\mathrm{C} 57 \mathrm{BL} / 6 \mathrm{~N}$ mice subjected to one-trial foreground contextual fear conditioning. Behav Brain Res 95:179-189.

Reul JMHM, De Kloet ER (1985) Two receptor systems for corticosterone in rat brain: microdistribution and differential occupation. Endocrinology 117:2505-2511.

Rudy JW, Morledge P (1994) Ontogeny of contextual fear conditioning in rats: implications for consolidation, infantile amnesia, and hippocampal system function. Behav Neurosci 108:227-234.

Rühmann A, Köpke AKE, Dautzenberg FM, Spiess J (1996) Synthesis and characterization of a photoactivable analog of corticotropinreleasing factor for specific receptor labeling. Proc Natl Acad Sci USA 93:10609-10613.

Rühmann A, Bonk I, Lin CR, Rosenfeld MG, Spiess J (1998) Structural requirements for peptidic antagonists of the corticotropin-releasing factor receptor (CRFR): development of CRFR2 $\beta$ selective antisauvagine-30. Proc Natl Acad Sci USA 95:15264-15269.

Schulkin J, Gold PW, McEwen BS (1998) Induction of corticotropinreleasing hormone gene expression by glucocorticoids: implication for understanding the states of fear and anxiety and allostatic load. Psychoneuroendocrinology 23:219-243.

Smith GW, Aubry J-M, Dellu F, Contarino A, Bilezikjian LM, Gold LH, Chen R, Marchuk Y, Hauser C, Bentley CA, Sawchenko PE, Koob GF, Vale W, Lee K-F (1998) Corticotropin releasing factor receptor 1-deficient mice display decreased anxiety, impaired stress response, and aberrant neuroendocrine development. Neuron 20:1093-1102.

Smith MA, Makino S, Kvetnansky R, Post RM (1995) Stress and glucocorticoids affect the expression of brain-derived neurotrophic factor and neurotrophin-3 mRNAs in the hippocampus. J Neurosci 15:1961-1970. 
Spiess J, Rivier J, Rivier C, Vale W (1981) Primary structure of corticotropin-releasing factor from ovine hypothalamus. Proc Natl Acad Sci USA 78:6517-6521.

Stenzel P, Kesterson R, Yeung W, Cone RD, Rittenberg MB, StenzelPoore MP (1995) Identification of a novel murine receptor for corticotropin-releasing hormone expressed in heart. Mol Endocrinol 9:637-645.

Stiedl O, Spiess J (1997) Effect of tone-dependent fear conditioning on heart rate and behavior of $\mathrm{C} 57 \mathrm{BL} / 6 \mathrm{~N}$ mice. Behav Neurosci 111:703-711.

Sutton RE, Koob GF, Je Moal M, Rivier J, Vale W (1982) Corticotropin releasing factor produces behavioural activation in rats. Nature 297:331-333.

Thomas E, Yadin E (1980) Multiple unit activity in the septum during Pavlovian aversive conditioning: evidence for an inhibitory role for the septum. Exp Neurol 69:50-60.

Timpl P, Spanagel R, Sillaber I, Kresse A, Reul JMHM, Stalla GK, Blanquet V, Steckler T, Holsboer F, Wurst W (1998) Impaired stress response and reduced anxiety in mice lacking a functional corticotropin-releasing hormone receptor 1 . Nat Genet 19:162-166.

Tsien JZ, Huerta PT, Tonegawa S (1996) The essential role of hippocampal CA1 NMDA receptor-dependent synaptic plasticity in spatial memory. Cell 87:1327-1338.

Vale W, Spiess J, Rivier C, Rivier J (1981) Characterization of a 41residue ovine hypothalamic peptide that stimulates secretion of corticotropin and $\beta$-endorphin. Science 213:1394-1397.

Vaughan J, Donaldson C, Bittencourt J, Perrin MH, Lewis K, Sutton S, Chan R, Turnbull AV, Lovejoy D, Rivier C, Rivier J, Sawchenko PE, Vale W (1995) Urocortin, a mammalian neuropeptide related to fish urotensin I and to corticotropin-releasing factor. Nature 378:287-292.

Vita N, Laurent P, Lefort S, Chalon P, Lelias J-M, Kaghad M, Le Fur G, Caput D, Ferrara P (1993) Primary structure and functional expression of mouse pituitary and human brain corticotrophin releasing factor receptors. FEBS Lett:335:1-5.

Yadin E, Thomas E (1981) Septal correlates of conditioned inhibition and excitation. J Comp Physiol Psychol 95:331-340. 